\title{
O NASCIMENTO DA CRIANÇA INDÍGENA AKWẼ XERENTE
}

Agripino Wakuke

Professor Alfabetizador

\section{Arlindo Wdêkruwe Xerente \\ Professor Alfabetizador}

\author{
Helena Krukwanẽ Xerente \\ Professora Alfabetizadora
}

\section{ROWASKUKTURÊ}

Akwẽ sĩ pikõ kkrapre mnõ wam pibumã, zatô aimõ wawẽ sĩ pikõ aikte zapari îtmã waihku nẽ hã si za rom mnõ adure tkrê sdasakra nwa kraprewa, aimõ psê snã krapre pibumã isipkrawa. Are tokto aiktde tmã waptkã pibumã tô sissum snã za simã tê kupar siwaihkâ snã, tazi za tokto aikte nnãkwa tê shâr pibumã za tkibu pko nã shâ are aikte, nĩpkrã waptkã pari za zdakwakre are se tkai krowi.

PALAVRAS-CHAVE: rêrêke. aikde; akwẽ.

\section{RESUMO}

Quando as crianças nascem na Aldeia, as anciãs fazem uma parteira tradicional. Somente aquela anciã que sabe tratar o parto da mulher e não é qualquer pessoa que pode fazer parto. Depois que nasceram as crianças, o umbigo é amarrado com corda de algodão depois cortado com pedaço de taquari, ao mesmo tempo após nascimento da criança também aparece o nascimento Placenta (aikte nipkrã) e cava um buraco dentro da casa para enterrar a placenta e pode ficar pra sempre. Depois que a mãe fez parto normal ela pode ficar dentro de casa de resguardo e não pode comer qualquer alimento e também o pai não pode trabalhar na roça nem carregar coisas pesadas. 
PALAVRAS-CHAVE: povo akwẽ. nascimento; criança.

Quando as crianças nascem na Aldeia, as anciãs fazem uma parteira tradicional. Somente aquela anciã que sabe tratar o parto da mulher e não é qualquer pessoa que pode fazer parto. Depois que nasceu a criança, o umbigo é amarrado com corda de algodão, depois é cortado com pedaço de taquari. Ao mesmo tempo, após nascimento da criança, também aparece o nascimento da Placenta (aikte nipkrã), e cava um buraco dentro da casa para enterrar a placenta e pode ficar pra sempre.

Depois que a mãe fez parto normal ela pode ficar dentro de casa de resguardo e não pode comer qualquer alimento e também o pai não pode trabalhar na roça nem carregar coisas pesadas. 